Bulletin of Electrical Engineering and Informatics

Vol. 10, No. 6, December 2021, pp. 3167 3177

ISSN: 2302-9285, DOI: 10.11591/eei.v10i6.3208

\title{
Micro hydropower plant potential study based on Landsat 8 operational land imager satellite data
}

\author{
Yuliana Susilowati ${ }^{1}$, Pudji Irasari ${ }^{2}$, Yugo Kumoro ${ }^{3}$, Wawan Hendriawan Nur $^{4}$, Yunarto \\ 1,3,4,5 Research Center for Geotechnology, Indonesian Institute of Sciences, Bandung, Indonesia \\ ${ }^{2}$ Research Center for Electrical Power and Mechatronics, Indonesian Institute of Sciences, Bandung, Indonesia
}

\begin{tabular}{l} 
Article Info \\
Article history: \\
Received Mar 19, 2021 \\
Revised Jul 2, 2021 \\
Accepted Sep 20, 2021 \\
\hline Keywords: \\
Data \\
Feasibility study \\
Hydropower potential study \\
Landsat 8 satellite \\
Micro hydropower plant \\
Potential study \\
Remote sensing
\end{tabular}

\begin{abstract}
Remote sensing technology has been widely applied in various fields, including oil, gas, and mineral exploration, spatial planning, and environmental monitoring. This paper describes the application of remote sensing technology for the potential study of a renewable micro hydropower plant (MHP) using Landsat 8 satellite data. The Sukaati Watershed, West Java, Indonesia, was selected as the case study area. Landsat 8 satellite data, acquired on August 21, 2020, was applied to extract information on land use, geology, and potential landslides. Drainage patterns, watershed boundaries, and head height were obtained from topographic map data. Drainage patterns, watershed boundaries, and land use are used to calculate flow rates. Geological map and landslide are the basis of layout of MHP components, such as water intake, dam, waterway, settling tank, penstock, and powerhouse. A field survey to acquire actual flow rate and head height was conducted to validate the results of the remote sensing data interpretation. Two potential sites of MHP were selected with a hydropower design of $129 \mathrm{~kW}$ and 5.18 MW. This study showed that remote sensing technology is beneficial for studying the potential of MHP because fieldwork can be done more quickly and efficiently.
\end{abstract}

This is an open access article under the CC BY-SA license.

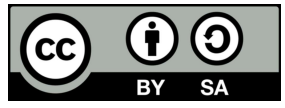

\section{Corresponding Author:}

Yuliana Susilowati

Research Center for Geotechnology

Indonesian Institute of Sciences

Komplek LIPI Sangkuriang Gedung 80, Bandung 40135, Indonesia

Email: yuli006@lipi.go.id

\section{INTRODUCTION}

The level of electricity expenditure can be observed as an assessment measure of a country's development level. The rise in the demand for energy worldwide is an affirmation that energy is the engine of growth in this 21 st century [1], [2]. Renewable hydropower is an alternative source of energy that can meet energy needs and reduce dependence on fossil energy sources. Renewable hydropower is a clean, reliable, versatile, and low-cost source of electricity generation [2]-[10].

Hydropower potential studies carry huge uncertainties about the technical, economic, and environmental feasibility. Building a hydropower plant requires thorough studies of water drainage patterns, geological lithology, surface and subsurface structures. Image processing technology can play a vital role in the studies of the categories mentioned. Detailed field studies can be followed, once image processing accomplishes the initial stage of the studies. Remote sensing technology can generate, maintain, and renew up-to-date data of the earth's surface and its combination with socio-economic information. Remote sensing and GIS technology are very helpful for the hydropower plant feasibility study [11]-[16]. 
Remote sensing and geographical information systems, with the development of satellite technologies, becomes possible to assess rapid and economic solutions for hydrology mapping, to determine a practical rainfall-runoff relation, water flow, particularly poorly gauged or ungauged basins [14], [17]-[28]. Remote sensing data is also useful for geological mapping. This method can minimize the cost and reduce the time of geological field surveys. The field survey can be done more effectively and more precisely [12], [13], [19], [21], [25], [29]-[33].

This study presents a methodology for utilizing Landsat 8 satellite data to study the potential for MHP. ER Mapper 7.3 and ArcGIS 10.3 are used for digital image processing and spatial data analysis. Utilizing satellite data through interpretation and analysis, geological, environmental (land use), hydrological, and other data are obtained to determine potential locations for MHP construction. The MHP study in the Cibuni river in Sukaati village is based on an estimate of the potential for electrical energy generated, which is quite large, which can be used for the tea processing industry, for the surrounding community who really need electricity for lighting and can be distributed to PLN (Indonesian state electricity company). The results of this interpretation are integrated with ground truth checks to validate to improve the accuracy of their interpretation further. Thus remote sensing data is proposed for the study of the potential of MHP in terms of minimizing costs and reducing the time of the preliminary survey of MHP. This paper also discusses the role of remote sensing in interpreting geology, land use, hydrology, and geological disasters, such as landslides in relation to the potential site of MHP, so that the sustainability of MHP infrastructure will be better maintained.

\section{RESEARCH METHOD}

Sukaati watershed, Cibuni river, West Java, Indonesia was selected as a case study area as shown in Figure 1. The Cibuni river originates on the western slopes of Mount Patuha II in the Rancabali district, Bandung regency, and empties into the Indian Ocean in Sindangbarang district, Cianjur regency. Ci Buni river has a length of $109 \mathrm{~km}$ and an area of $1,434.70 \mathrm{~km} 2$ covering three districts, the Cianjur, Bandung, and Sukabumi regency. With a large catchment area and a large discharge, the Cibuni River is a potential water resource that is used for various needs, including drinking water, irrigation, and flushing as well as generating electricity.

Cibuni river flows along the southwestern region of the island of Java, which has a tropical rainforest climate (code: Af according to the Köppen-Geiger climate classification). The annual average temperature is around $18^{\circ} \mathrm{C}$. The warmest month is October at an ordinary $20^{\circ} \mathrm{C}$, and the coldest month is August at a regular $18^{\circ} \mathrm{C}$. The average highest rainfall is in December at $570 \mathrm{~mm}$, and the lowest is in September at $53 \mathrm{~mm}$. The annual rainfall is high, between $2239 \mathrm{~mm}$ to $5779 \mathrm{~mm}$. The average annual rainfall is $3766 \mathrm{~mm}$. The preliminary reading of the RBI contour map showing drainage patterns, watershed boundaries, and potential heads identified two potential sites of MHP, Site 1 (Indragiri site), and Site 2 (Sukaati site).
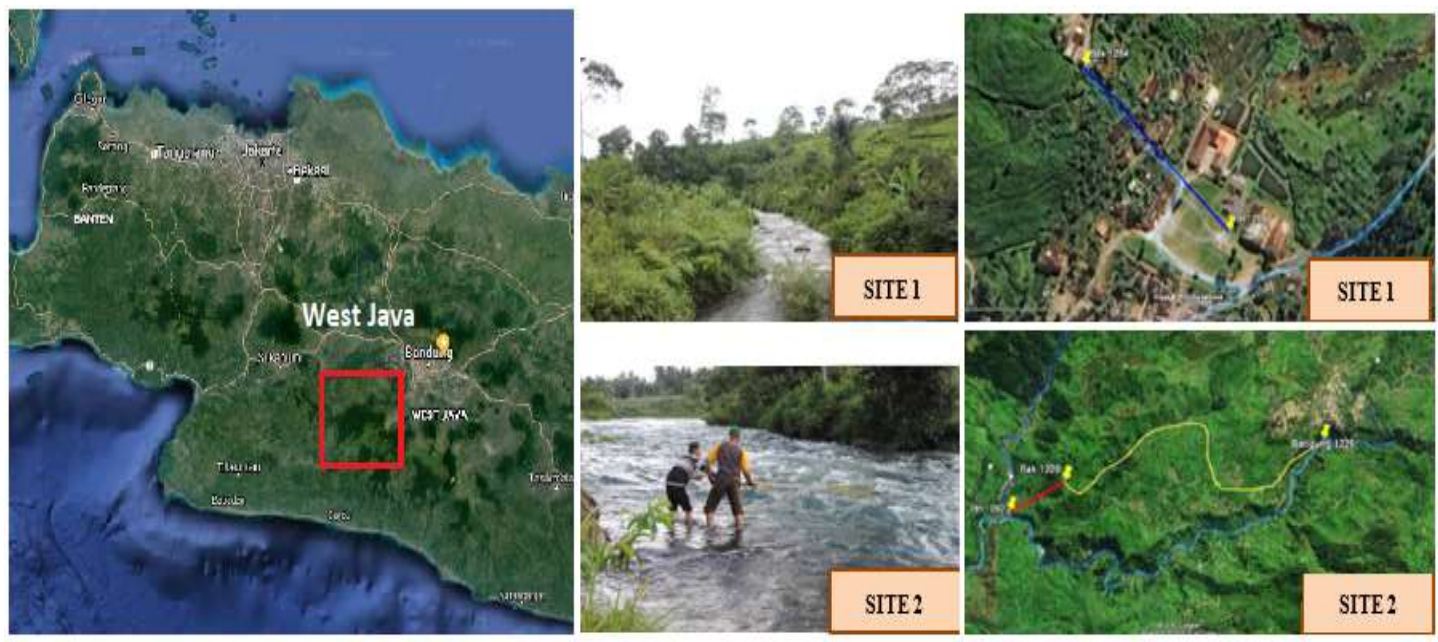

Figure 1. Study area, Site 1 (Indragiri site), and Site 2 (Sukaati site), Sukaati watershed, Cibuni River, West Java, Indonesia

Bulletin of Electr Eng \& Inf, Vol. 10, No. 6, December 2021 : 3167-3177 
By deploying remote sensing data interpretation such as mapping drainage pattern, watershed boundary, land use, geology, and potential landslide, several tasks of MHP potential studies can be covered. The research method is presented in Figure 2. The utilization of Landsat 8 satellite data was to create land use, geology, and potential landslide maps. The base map published by Geospatial Information Agency of Indonesia, with a scale of 1:25.000, was the basis for making a topographic, drainage pattern, and watershed boundary map.

The estimated flow rate was calculated from the drainage pattern, watershed boundary and land use spatial data. The head was estimated from the topographic map. Afterward, the geological and potential landslide map was used for layout design of MHP components, such as water intake, dam, waterway, settling tank, penstock, and powerhouse. Field measurement is performed to measure the head and water flow rate.

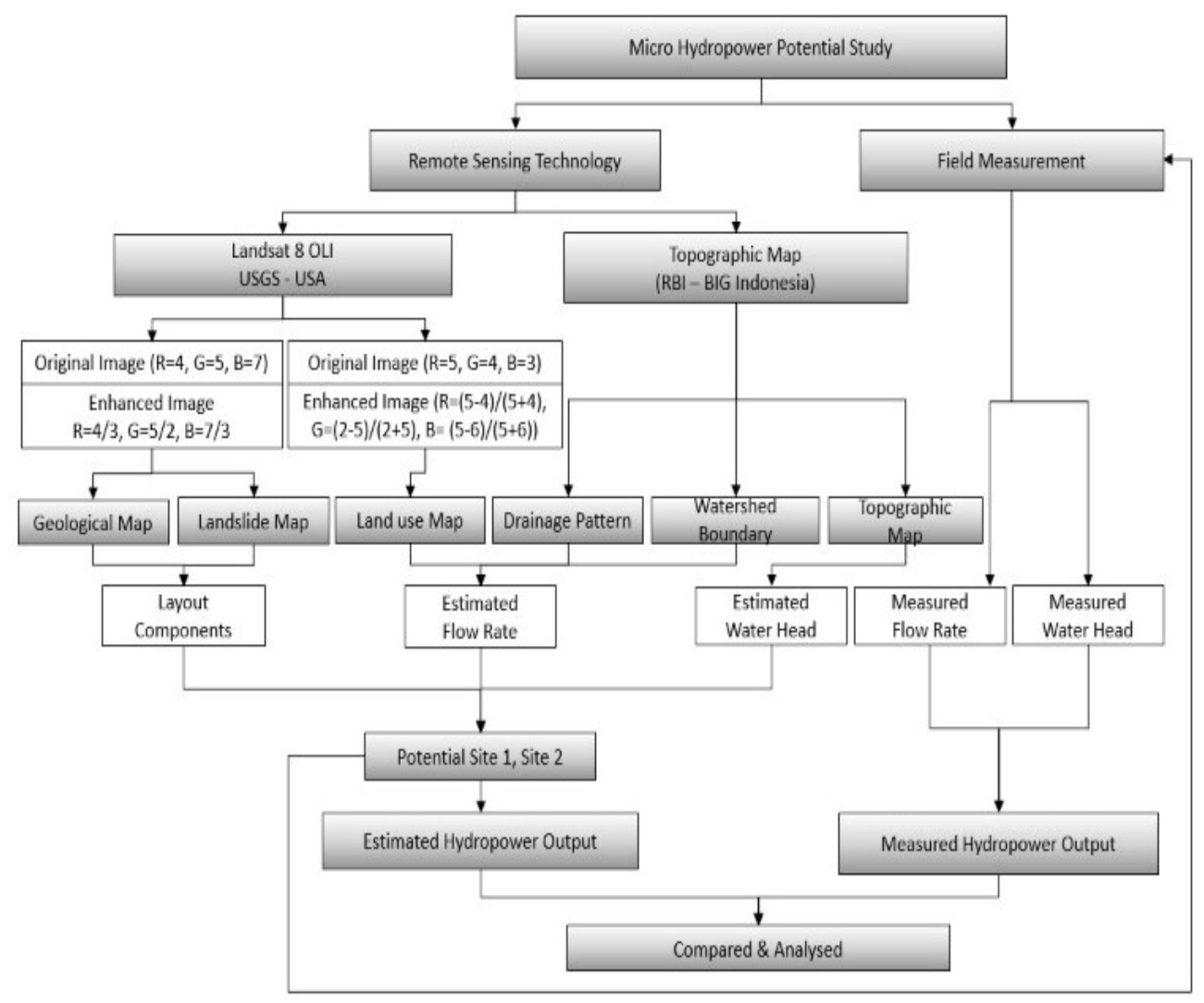

Figure 2. Research method

The hydrological study aims to determine whether the available water discharge and plunge height can drive the turbine according to the desired power. The hydropower potential study includes measuring the minimum discharge flowing in a water channel/river, water discharge during a flood, and available waterfall height (height difference). The generated hydropower is calculated using:

$$
\mathrm{P}=\mathrm{g} \times \mathrm{Q} \times \mathrm{H} \times \eta
$$

where: $\mathrm{P}=$ estimated hydropower $(\mathrm{kW}), \mathrm{g}=$ gravity $\left(\mathrm{m} / \mathrm{s}^{2}\right), \mathrm{Q}=$ flow rate $\left(\mathrm{m}^{3} / \mathrm{s}\right), \mathrm{H}=$ effective head $(\mathrm{m})$, $\eta=$ system efficiency $=80(\%)$.

\subsection{Head and flow rate estimation}

Related to the head and flow rate calculation, the head, drainage pattern and watershed boundary can easily be identified from the digital elevation model (DEM) extracted from a topographic map. The vector data of the drainage patterns map can be overlaid to the raster image for comprehensive reading [34]-[38]. 
Topographic studies include collecting data and information on the best location to obtain adequate water drop height, intake penstock, and tailrace. Based on topographic map, it can be identified two potential MHP site, Site 1, Indragiri watershed with a potential head of $25 \mathrm{~m}$, and Site 2 Sukaati watershed with a potential head of $125 \mathrm{~m}$. Parameters for calculating water flow consist of precipitation, catchment area, and type of land cover in the catchment area. Water flow is obtained from as shown in (2), (3):

$$
\mathrm{Q}=0.00278 \text { Cws } \times \text { I x A }
$$

$$
C_{w S}=\frac{\sum_{i=1}^{n} C_{\mathrm{i}} A_{\mathrm{i}}}{\sum_{i=1}^{n} A_{i}}
$$

where: Q is the water flow (m3/s), Cws is the runoff coefficient (depend on the land cover/land use), I is the precipitation ( $\mathrm{mm} /$ hour), $\mathrm{A}$ is the watershed area (ha), $\mathrm{Ai}$ is the land area with land cover type $\mathrm{i}, \mathrm{Ci}$ is the runoff coefficient of the ground cover type $i, n$ is the number of land cover types.

The precipitation data was provided by the rainfall gauge station data belonging to PTPN VIII Tea Plantation. Rainfall data is the average monthly rainfall obtained from measurement data for 20 years, from 2000 to 2019. Land use is divided into four classes with a runoff coefficient values listed in Table 1.

\begin{tabular}{cc} 
Table 1. Coefficient runoff in study area \\
\hline Land use/Land cover & Runoff coefficient $(\mathrm{C})$ \\
\hline Forest Land & $0.10-0.40$ \\
Agriculture Land & $0.40-0.50$ \\
Built-Up Land & $0.50-0.70$ \\
Bare Land & $0.70-0.95$ \\
\hline
\end{tabular}

The land use map was interpreted based on the land cover identification of remote sensing data. Land cover refers to the physical and biological covering up the land's surface, including water, vegetation, bare land, or artificial structures. Land use relates to human activities such as agriculture, forestry, as well as build up area. The land cover may be observed directly in the field or by remote sensing. Observations of landuse need to integrating social and natural scientific approaches to decide which human activities occur in various landscape parts, even when land cover appears to be the same.

A Landsat 8 satellite data of the study area was downloaded from earth explorer-United States geological survey (USGS) with path type WRS 122 and Row 065. The acquisition date is August 21, 2020. The projection is UTM WGS84 Zone 46. Landsat 8 is the newest Landsat satellite launched and brings the operational land imager (OLI) and the thermal infrared sensor (TIRS) instrument. There are nine spectral bands of OLI and two spectral bands of TIRS. The Landsat 8 contains invisible multispectral bands and infrared bands. The layer of the multispectral bands consists of near-infrared (NIR), short-infrared (SWIR), red and green are employed as shown in Table 2.

Table 2. Landsat 8 OLI/TIRS [39]

\begin{tabular}{lcc}
\hline \multicolumn{1}{c}{ Band Designations } & Wave Length & Spatial Resolution \\
\hline Band 1 (Coastal Aerosol) & $(0.43-0.45 \mu \mathrm{m})$ & $30 \mathrm{~m}$ \\
Band 2 (Blue) & $(0.45-0.51 \mu \mathrm{m})$ & $30 \mathrm{~m}$ \\
Band 3 (Green) & $(0.53-0.59 \mu \mathrm{m})$ & $30 \mathrm{~m}$ \\
Band 4 (Red) & $(0.64-0.67 \mu \mathrm{m})$ & $30 \mathrm{~m}$ \\
Band 5 (Infrared) & $(0.85-0.88 \mu \mathrm{m})$ & $30 \mathrm{~m}$ \\
Band 6 (Short wave infrared) & $(1.57-1.65 \mu \mathrm{m})$ & $30 \mathrm{~m}$ \\
Band 7 (Short wave infrared) & $(2.11-2.29 \mu \mathrm{m})$ & $30 \mathrm{~m}$ \\
Band 8 (Pancromatic) & $(0.50-0.68 \mu \mathrm{m})$ & $15 \mathrm{~m}$ \\
Band 9 (Cirrus) & $(1.36-1.38 \mu \mathrm{m})$ & $30 \mathrm{~m}$ \\
Band 10 (TIRS) & $(10.6-11.19 \mu \mathrm{m})$ & $100 \mathrm{~m}$ \\
Band 11 (TIRS) & $(11.5-12.51 \mu \mathrm{m})$ & $100 \mathrm{~m}$ \\
\hline
\end{tabular}

In this study, Landsat 8 OLI data is used for land use, geology, and landslides mapping. Land use mapping is carried out using a combination of band 5 (near infra-red/NIR), band 4 (Red), and band 3 (Visible Red). The Landsat 8 OLI was extracted to enhance the land cover features. The combination of bands can interpret the characteristics of the object, such as vegetation, water, and developed areas [40]. The normalized difference vegetation index (NDVI) represents the vegetation. Vegetation is a mathematical combination between the red and NIR band, which indicates vegetation's presence and condition. The

Bulletin of Electr Eng \& Inf, Vol. 10, No. 6, December 2021 : 3167-3177 
normalized difference water index (NDWI) represents the water by estimate the leaf water content and monitoring changes related to water content in water bodies. The NDWI uses a near-infrared and green band to enhance characteristics while eliminating soil and terrestrial vegetation. The normalized difference builtup index (NDBI) represents the built-up area. The NDBI uses a combination of the NIR band and SWIR band to highlight built-up areas automatically. The NDVI, NDWI, and NDBI were determined by utilizing the formulas (4), (5), and (6):

$$
\begin{aligned}
& \mathrm{NDVI}=(\mathrm{NIR}-\mathrm{Red}) /(\mathrm{NIR}+\mathrm{Red})=(\text { Band } 5 \text {-Band } 4) /(\text { Band } 5+\mathrm{Band} 4) \\
& \mathrm{NDWI}=(\text { Green-NIR }) /(\text { Green }+\mathrm{NIR})=(\text { Band } 2-\text { Band } 5) /(\text { Band } 2+\mathrm{Band} 5) \\
& \mathrm{NDBI}=(\text { Green-SWIR }) /(\text { Green }+\mathrm{SWIR})=(\text { Band } 5 \text {-Band } 6) /(\text { Band } 5+\text { Band } 6)
\end{aligned}
$$

\subsection{Geological study}

The geological study aims to convince various parties that the micro-hydro development program is technically feasible and suitable to support the development of MHP. Data and information required in the geological study include topographical and geological that will be used for the main building and drainage routes. The geological condition must support the quality of the core building, which consists of a dam, intake, water way, settling tank, penstock and power house. According to landslide prevalence, geology is a prime factor, hence the necessity to create a structural pattern map, faults map, and river channel map in a highly rugged volcanic mountainous terrain [41]. Geological data is obtained from a combination of image interpretation, topographic map interpretation and field checks to determine accuracy in the analysis of rock types and geological structures. Regional geological data refers to the geological map sheet Sindang Barang and Bandarwaru [42].

Remote sensing data is helpful for geological mapping [36], [43], [44]. In geological mapping, reflectance information of rocks in the SWIR and emissivity of the rocks in the TIR are noteworthy. In Landsat 8, SWIR is available in Band 6 and 7; TIR is available in Band 10, 11. In general, combinations involving bands from each spectral region (visible, mid-infrared, and SWIR II) display the most contrast on lithological that makes Landsat $8(\mathrm{R}=4, \mathrm{G}=5, \mathrm{~B}=7)$ were enhanced further using histogram equalization contrast enhancement accordingly. In this study, geological and landslide mapping was carried out using a combination of band 4 (Red), band 5 (NIR), band 7 (Shortwave Infra-Red). Band rationing and combinations with most contrast for band ratios involving geology is a higher band divided by a lower one. Combinations $(4 / 3,5 / 2,7 / 3)$ were selected for geological mapping. Field geological checks are carried out to determine rock types and other geological information related to micro hydro development.

\section{RESULTS AND DISCUSSION}

\subsection{Flow rate estimation}

Landsat 8 OLI imagery in the form of a combination of visible wave and NIR bands is applied to obtain information on land cover and land use. Afterward, a vegetation index, water index, and build-up index are formulated. NDVI, NDWI, and NDBI data are displayed as a composite image and serve as a classification reference for making land use maps as shown in Figure 3 (a) and (b). An enhanced image provides better information for interpreting Landuse, Land cover as well as geology and landslide mapping.

To obtain lithology information, Landsat $8 \mathrm{OLI}$ imagery was used in the form of a combination of NIR and SWIR bands. Band rationing and assimilations $(4 / 3,5 / 2,7 / 3)$ have the best contrast and form the input for the classification of geological mapping as shown in Figure 3 (c) and (d).

The interpretation of Land-use is displayed in Land use map as shown in Figure 4. It appears that the study area is mostly plantation and forest, which has a low run-off coefficient. Land cover in the form of forests and vegetation causes a small fluctuation of flow rate, which means proper for the sustainability of MHP. Based on the remote sensing interpretation, the Indragiri watershed with 1,595 ha catchment area has a potential discharge of $1.30 \mathrm{~m}^{3} / \mathrm{s}$, while Sukaati Watershed has a water catchment area of 6,515 ha and yields a $10.2 \mathrm{~m}^{3} / \mathrm{s}$ flow rate. The land cover in the study area is relatively homogeneous, namely in the form of forests in the upstream and tea plantations in the hills. The owner of the case study area is Forestry and Tea Plantation Company. Land tenure by Forestry and Tea Plantation Company will facilitate the management of water infiltration in the catchment area. Forest and tea plantations land cover will provide benefits to maintain the stability of the flow rate required for MHP, reduces the risk of erosion and landslides. Landslides mainly occur in steep river valleys due to vertical erosion of water. 


\subsection{Geological study and head estimation}

The physiography of the research area is the volcanic mountains of south Bandung, this is shown by its morphology such as cones and volcanic craters, then the shape of steep river grooves and valleys with heavy water flows. The geological interpretation is presented in geological map in Figure 5. The main river of the study area is the Cibuni River, which originates at Mount Patuha and Mount Kendeng, flows to the southwest, and empties into the Indonesian Ocean. Brook form steep and sheer incisions forming a radial pattern upstream and developing dendritic downstream. In the study area, all pyroclastic rocks are the structure of products of volcanic activity, namely Mount Kendang (Qlk) in the northern part, which is an old volcano with cranial remains on it. Mount Patuha (Qvp) is on the eastern side with its parasitic crater in the form of a white crater and a lake of Patenggang is in the middle. The rocks consist of andesite lava, breccia, and sandy tuff containing pumice and lava deposits in Figure 6. River erosion tends to be vertical, indicated by the steep and sheer river valleys. The geological conditions of the study area provide an overview of the carrying capacity of the land for MHP development. It is of concern for civil construction design. The thickness of weathered soil and the high fertility rate of volcanic rocks make this area very suitable for tea plantations and community fields.

The results of the Landslide potential interpretation is presented in landslide map in Figure 7. There are several locations with high landslide potential (the areas in red). Feature of potential Landslide in the image has a specific characteristic of the landslide crown, steep walls of the topographic valley, and rivers that differ from the surrounding slopes. Steep river valleys in soft and unstable rock types are a potential landslide zone. In volcanic rocks, generally, the weathering is very thick due to high rainfall and high slope levels. In general, soil movements occur in valleys or slopes composed of weathering soil from breccia and tuffs. In this study, areas with high landslide potential are generally not in the Sukaati catchment area. This result signifies that the Sukaati Watershed is the potential for the construction of MHP. Areas prone to landslides can be avoided by designing a more detailed site plant design.

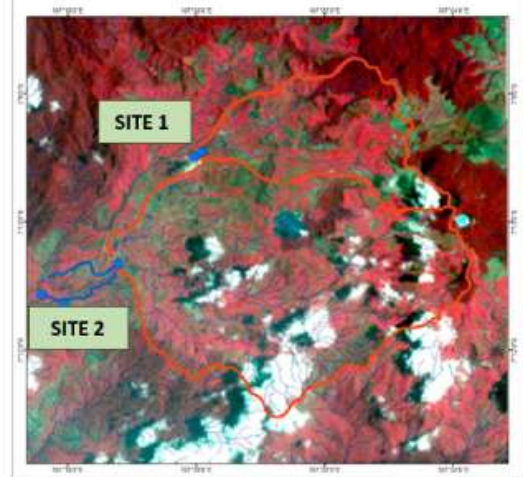

(a)

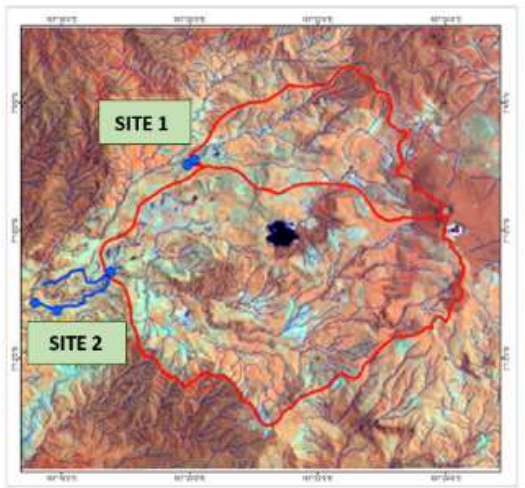

(c)

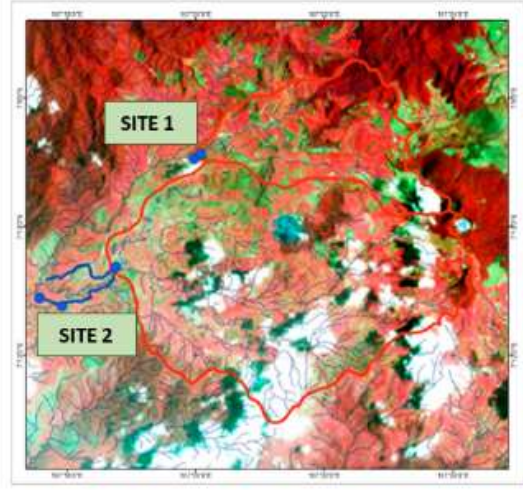

(b)

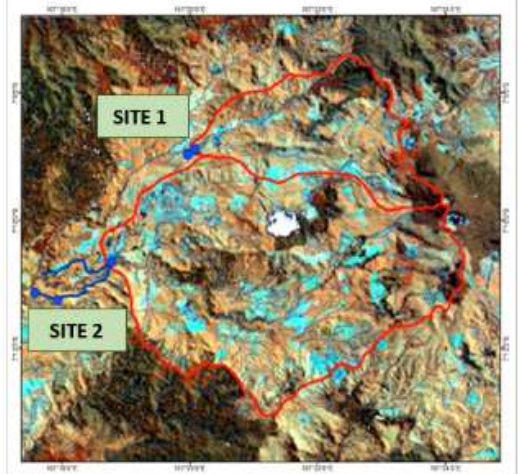

(d)

Figure 3. Show, (a) original image of Landsat 8 OLI $(R=5 \mathrm{G}=4, \mathrm{~B}=3)$, (b) enhanced image of Landsat 8 OLI $(\mathrm{R}=\mathrm{NDVI}=(5-4) / 5+4), \mathrm{G}=\mathrm{NDWI}=(2-5) /(2+5), \mathrm{B}=\mathrm{NDBI}=(5-6) /(5+6)),(\mathrm{c})$ original image of Landsat 8 OLI $(R=4, G=5, B=7),(d)$ enhanced image of of Landsat 8 OLI $(R=4 / 3, G=5 / 2, B=7 / 3)$

Bulletin of Electr Eng \& Inf, Vol. 10, No. 6, December 2021 : 3167-3177 


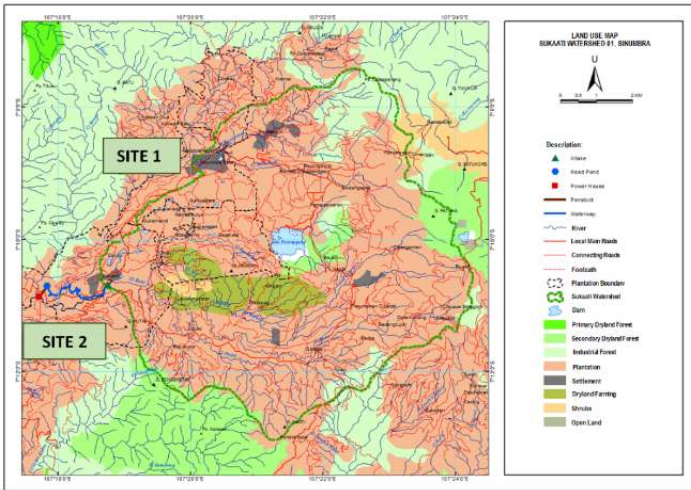

Figure 4. Land use map of Sukaati watershed

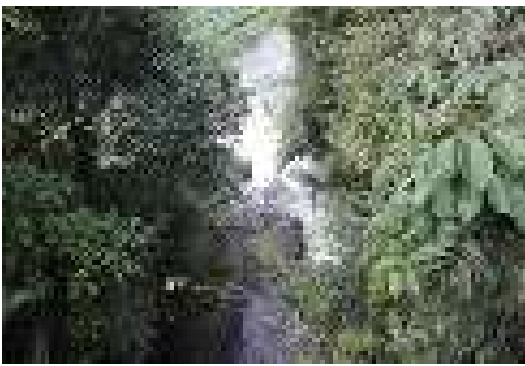

(a)

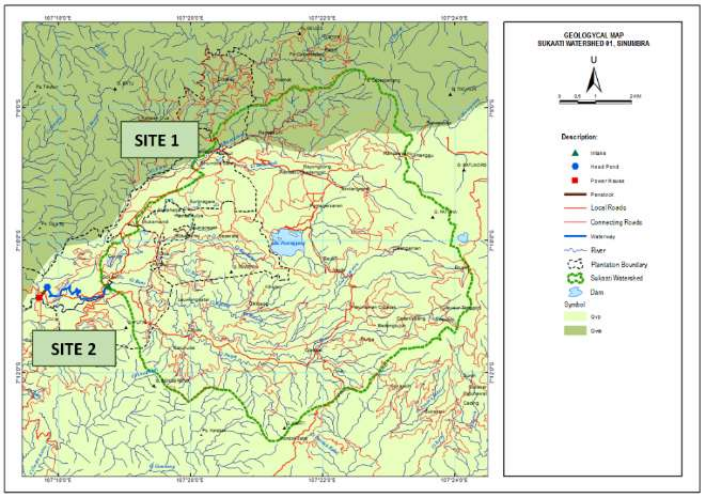

Figure 5. Geological map of Sukaati watershed

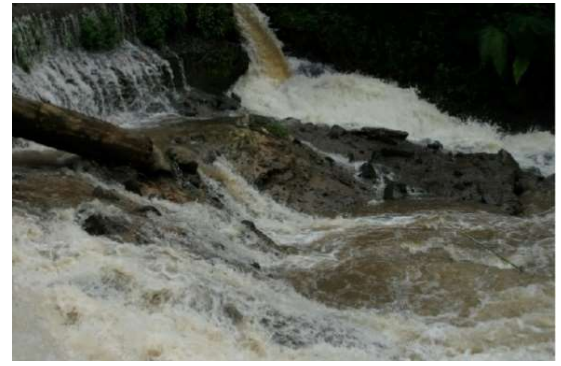

(b)

Figure 6. Photo of outcrop on the cibuni river in the Sukaati area with steep river valleys, (a) andesite lava, (b) lava breccia

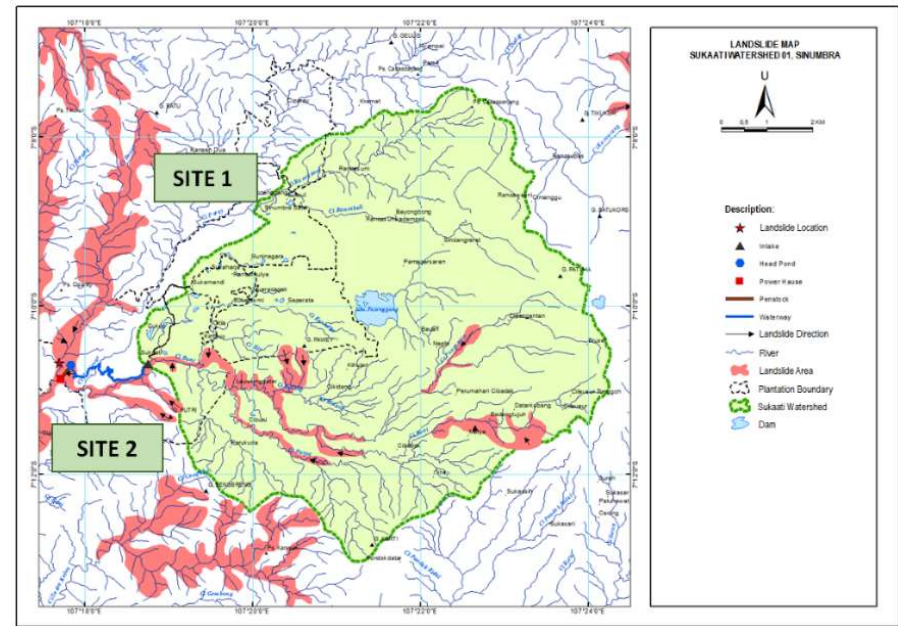

Figure 7. Landslide map of Sukaati watershed

\subsection{Field measurement results and comparative analysis}

Field measurement is performed to verify the results of remote sensing interpretation. Measurements were conducted in August 2020 (the dry season when discharge is minimum). The flow rate is obtained by multiplying the water velocity measured using a flow meter, and the cross-sectional area of the river. All the head and flow rate data from measurements and the remote sensing interpretation are then used to calculate the hydropower output as shown in Table 3. 
Table 3. Comparative analysis of MHP potential site

\begin{tabular}{|c|c|c|c|c|c|c|c|}
\hline \multirow{2}{*}{ Description } & \multirow{2}{*}{ Unit } & \multicolumn{3}{|c|}{ Site 1} & \multicolumn{3}{|c|}{ Site 2} \\
\hline & & Estimated & Measured & Designed & Estimated & Measured & Designed \\
\hline Catchement Area & ha & & 1,595 & & & 6,515 & \\
\hline Potential Flow & $\mathrm{m}^{3} / \mathrm{s}$ & 1.30 & 1.21 & 0.80 & 10.20 & 8.88 & 6.00 \\
\hline Potential Head & $\mathrm{m}$ & 25.00 & 22.00 & 20.60 & 125.00 & 120.00 & 110.00 \\
\hline Potential Power & $\mathrm{kW}$ & 255.00 & 182.00 & 129.00 & $10,000.00$ & $8,365.00$ & $5,180.00$ \\
\hline
\end{tabular}

The differences between the hydropower estimation and measurement are $39 \%$ and $20 \%$ for Site 1 and Site 2 consecutively. The proposed hydropower design considers the minimum flow and risk factors for changes that may occur. There fore the head and flow rate design are set to be smaller than that of the estimation and measurement.

Remote sensing interpretation generally produces overestimated values compared to the measurement data due to less detail of the data resolution and the map scale used. However, the results of the remote sensing interpretation can give an idea of the existing potential so that it so can be used as a basis for assessing the hydropower potential in an area, especially the ones with inadequate measurement data. Detailed measurements in the field are needed to validate data and obtain more precise results.

\section{CONCLUSION}

This paper discusses the potential study of MHP with the help of Landsat 8 OLI satellite data. Sukaati watershed, Cibuni river, West Java was chosen because it has great potential for electrical energy used for industry or society. The methodology integrates interpretation of satellite imagery and field surveys related to geological conditions, topography, land cover, environment, and geological disasters such as landslides. The main constituent rocks are volcanic rocks, namely breccia and andesite lava, with land cover dominated by tea plantations. The low potential for landslides greatly supports the construction of the MHP. The results of satellite data interpretation of geological conditions, land cover, topography, and geological disasters show two potential locations for MHP, suitable for hydroelectric power plants with $129 \mathrm{~kW}$ and $5.18 \mathrm{MW}$ hydropower designs. However, detailed surveys and field measurements are still needed to validate the interpretation and analysis of remote sensing imagery results.

\section{CONTRIBUTORS}

All authors have a similar contribution as the main contributor to the article.

\section{ACKNOWLEDGEMENTS}

This research was supported by PTPN VIII. Thank you very much to Ir. Yogi Subyaktiyana, PTPN VIII, for his constructive discussion, Ir. Suwijanto for his guidance in interpreting visual imagery and conventional geological mapping, and the Head of the Research Center for Geotechnology, Indonesian Institute of Sciences for his support in this research.

\section{REFERENCES}

[1] F. Adedoyin, I. Abubakar, F. V. Bekun and S. A. Sarkodie, "Generation of energy and environmental-economic growth consequences: Is there any difference across transition economies?," Energy Reports, vol. 6, pp. 1418-1427, 2020, doi: 10.1016/j.egyr.2020.05.026.

[2] World Bank and ESMAP, "Small Hydropower Resource Mapping in Indonesia," no. March. Washington: The World Bank, $2017 . \quad$ [Online]. Available: https://documents1.worldbank.org/curated/en/891911506073273340/pdf/119859-ESM-P145273-PUBLICIndonesiaSmallHydropowerMappingReportWBESMAPMarch.pdf.

[3] D. P. D. Suparyawan, I. N. S. Kumara and W. G. Ariastina, "Study of micro hydropower plant planning in Sambangan Village, Buleleng Regency, Bali," Majalah Ilmiah Teknologi Elektro, vol. 12, no. 2, 2013, doi: 10.24843/10.24843/MITE.

[4] G. Aghajani and N. Ghadimi, "Multi-objective energy management in a micro-grid," Energy Reports, vol. 4, pp. 218-225, 2018, doi: 10.1016/j.egyr.2017.10.002.

[5] G. Pambudi and N. Nananukul, "Wind turbine site selection in Indonesia, based on a hierarchical dual data envelopment analysis model," Energy Procedia, vol. 158, pp. 3290-3295, 2019, doi: 10.1016/j.egypro.2019.01.980.

[6] J. I. Razan, R. S. Islam, R. Hasan, S. Hasan and F. Islam, "A Comprehensive Study of Micro-Hydropower Plant and Its Potential in Bangladesh," International Scholarly Research Notices, vol. 2012, pp. 1-10, 2012, doi: $10.5402 / 2012 / 635396$.

Bulletin of Electr Eng \& Inf, Vol. 10, No. 6, December 2021 : 3167-3177 
[7] D. Adu, J. Zhang, Y. Fang, L. Suoming and R. O. Darko, "A Case Study of Status and Potential of Small HydroPower Plants in Southern African Development Community," Energy Procedia, vol. 141, pp. 352-359, 2017, doi: 10.1016/j.egypro.2017.11.042.

[8] S. Chakraborty, M. I. Ahmad, A. Guin, S. Mukherjee, R. Doswami and R. Roy, "Hydropower: Its Amazing Potential- A Theoretical Perspective," Journal of Civil and Environmental Engineering, vol. 2, no. 12, pp. 56-60, 2015.

[9] S. J. van Vuuren, C. L. Blersch and M. van Dijk, "Modelling the feasibility of retrofitting hydropower to existing South African dams," Water SA, vol. 37, no. 5, pp. 679-692, 2011, doi: 10.4314/wsa.v37i5.5.

[10] C. S. Kaunda, C. Z. Kimambo and T. K. Nielsen, "Potential of Small-Scale Hydropower for Electricity Generation in Sub-Saharan Africa," International Scholarly Research Notices, vol. 2012, pp. 1-15, 2012, doi: $10.5402 / 2012 / 132606$.

[11] S. Athayde et al., "Mapping research on hydropower and sustainability in the Brazilian Amazon: advances, gaps in knowledge and future directions," Current Opinion in Environmental Sustainability, vol. 37, pp. 50-69, 2019, doi: 10.1016/j.cosust.2019.06.004.

[12] N. Avisse, A. Tilmant, M. François Müller and H. Zhang, "Monitoring small reservoirs' storage with satellite remote sensing in inaccessible areas," Hydrology and Earth System Sciences Discussions, vol. 21, no. 12, pp. 64456459, 2017, doi: 10.5194/hess-21-6445-2017.

[13] A. Basith, "Landslide Susceptibility Modeling Under Environemental Changes: A Case Study of Cameron Highlands, Malaysia," Thesis, University of Technology Petronas, 2011, doi: 10.13140/RG.2.2.35707.00806.

[14] Y. Tian, F. Zhang, Z. Yuan, Z. Che and N. Zafetti, "Assessment power generation potential of small hydropower plants using GIS software," Energy Reports, vol. 6, pp. 1393-1404, 2020, doi: 10.1016/j.egyr.2020.05.023.

[15] R. de C. Condé et al., "Indirect assessment of sedimentation in hydropower dams using MODIS remote sensing images," Remote Sensing, vol. 11, no. 3, 2019, doi: 10.3390/rs11030314.

[16] W. H. Nur, Yuliana, Y. Susilowati, Y. Kumoro and Yunarto, "Overview about gis multi-criteria spatial analysis for micro hydropower plant site suitability in south ogan komering ulu district, south sumatera, indonesia," Bulletin of Electrical Engineering and Informatics (BEEI), vol. 10, no. 2, pp. 1024-1034, 2021, doi: 10.11591/eei.v10i2.2770.

[17] R. M. A. Fesalbon and A. C. Blanco, "Hydropower dam site selection and visualization using GIS and RS techniques: a case of marinduque, Philippines," The International Archives of Photogrammetry, Remote Sensing and Spatial Information Sciences, vol. XLII-4/W19, pp. 207-214, 2019, doi: 10.5194/isprs-archives-XLII-4-W19207-2019.

[18] S. Vidhya and L. G. R. Sarvani, "Selection of Suitable Sites for Small Hydropower Plants Using Geo-Spatial Technology," International Journal of Pure and Applied Mathematics, vol. 119, no. 17, pp. 217-240, 2018.

[19] B. R. Gan, X. G. Yang and J. W. Zhou, "GIS-based remote sensing analysis of the spatial-temporal evolution of landslides in a hydropower reservoir in southwest China," Geomatics, Natural Hazards and Risk, vol. 10, no. 1, pp. 2291-2312, 2019, doi: 10.1080/19475705.2019.1685599.

[20] D. G. Larentis, W. Collischonn, F. Olivera and C. E. M. Tucci, "Gis-based procedures for hydropower potential spotting," Energy, vol. 35, no. 10, pp. 4237-4243, 2010, doi: 10.1016/j.energy.2010.07.014.

[21] M. Pathak, "Application of GIS and Remote Sensing for Hydropower Development in Nepal," Hydro Nepal Journal of Water Energy and Environment, vol. 3, no. 3, pp. 42-45, 2009, doi: 10.3126/hn.v3i0.1920.

[22] P. Punys, A. Dumbrauskas, A. Kvaraciejus and G. Vyciene, "Tools for small hydropower plant resource planning and development: A review of technology and applications," Energies, vol. 4, no. 9, pp. 1258-1277, 2011, doi: 10.3390/en4091258.

[23] A. Rani and R. Kumar, "Geospatial Information Support for Power Projects," Journal of Remote Sensing \& GIS, vol. 07, no. 04, pp. 2-6, 2018, doi: 10.4172/2469-4134.1000251.

[24] V. Sammartano, L. Liuzzo and G. Freni, "Identification of potential locations for run-of-river hydropower plants using a GIS-based procedure," Energies, vol. 12, no. 18, pp. 1-20, 2019, doi: 10.3390/en12183446.

[25] A. Shumba, S. Togarepi, W. Gumindoga, T. Masarira and E. Chikuni, "A remote sensing and GIS based application for monitoring water levels at Kariba dam.," ACRID, no. January, 2018, doi: 10.4108/eai.20-62017.2270774

[26] A. K. Sinha, "GIS database management for planning of Hydel Power Generation," 2003, [Online]. Available: http://luiscosta.free.fr/Docs/Hydel Power Generation.pdf.

[27] A. Kawasaki, S. Yosida and S. Sadohara, "Outline of the water resources GIS application, Arc Hydro and case studies in the United States," Theory and Applications of GIS, vol. 15, no. 1, pp. 29-37, 2007, doi: $10.5638 /$ thagis. 15.29

[28] A. Senta and S. Ljiljana, "Remote sensing data driven bathing water quality assessment using sentinel-3," Indonesian Journal of Electrical Engineering and Computer Science (IJEECS), vol. 21, no. 3, pp. 1634-1647, 2021, doi: 10.11591/ijeecs.v21i3.pp1634-1647.

[29] H. T. El-Madany, F. H. Fahmy, N. M. A. El-Rahman and H. T. Dorrah, "Optimization and feasibility analysis of satellite earth station power system using homer," TELKOMNIKA Indonesian Journal of Electrical Engineering, vol. 10, no. 2, pp. 359-370, 2012, doi: 10.12928/telkomnika.v10i2.812.

[30] J. Grett and T. Fay, "Small Hydropower Potential Assessment using Remote Sensing and Hydrological Data - The hydroMinds Model," Technical Report and Model Presentation, pp. 1-5, 2014.

[31] A. G. Konings, K. Rao and S. C. Steele-Dunne, "Macro to micro: microwave remote sensing of plant water content for physiology and ecology," New Phytologist, vol. 223, no. 3, pp. 1166-1172, 2019, doi: 10.1111/nph.15808.

[32] E. Zell, J. Engel-Cox, R. Eckman and P. Stackhouse, "Application of Satellite Sensor Data and Models for Energy Management," in IEEE Journal of Selected Topics in Applied Earth Observations and Remote Sensing, vol. 1, no. 
1, pp. 5-17, March 2008, doi: 10.1109/JSTARS.2008.2001142.

[33] M. Asri, H. Mohd, A. N. Othman, Z. A. Latif and Z. M. Yusoff, "GIS based probabilistic method in sinkhole susceptibility hazard zones," Indonesian Journal of Electrical Engineering and Computer Science (IJEECS), vol. 16, no. 3, pp. 1539-1546, 2019, doi: 10.11591/ijeecs.v16.i3.pp1539-1546.

[34] S. Carver, N. Mikkelsen and J. Woodward, "Long-term rates of mass wasting in Mesters Vig, northeast Greenland: Notes on a re-survey," Permafrost and Periglacial Processes, vol. 13, pp. 243-249, 2002, doi: 10.1002/ppp.421.

[35] C. Doña et al., "Monitoring hydrological patterns of temporary lakes using remote sensing and machine learning models: Case study of La Mancha Húmeda Biosphere Reserve in Central Spain," Remote Sensing, vol. 8, no. 8, p.618, 2016, doi: 10.3390/rs8080618.

[36] Y. Gao and W. Zhang, "LULC classification and topographic correction of Landsat-7 ETM+ Imagery in the Yangjia river Watershed: The influence of DEM resolution," Sensors, vol. 9, no. 3, pp. 1980-1995, 2009, doi: $10.3390 / \mathrm{s} 90301980$.

[37] M. Hassani, M. C. Chabou, M. Hamoudi and M. S. Guettouche, "Index of extraction of water surfaces from Landsat 7 ETM+ images," Arabian Journal of Geosciences, vol. 8, no. 6, pp. 3381-3389, 2014, doi: 10.1007/s12517-014-1475-y.

[38] M. F. O. Khattab and B. J. Merkel, "Application of landsat 5 and landsat 7 images data for water quality mapping in Mosul Dam Lake, Northern Iraq," Arabian Journal of Geosciences, vol. 7, no. 9, pp. 3557-3573, 2013, doi: 10.1007/s12517-013-1026-y.

[39] D. Jeevalakshmi, S. Narayana Reddy and B. Manikiam, "Land surface temperature retrieval from landsat data using emissivity estimation," International Journal of Applied Engineering Research, vol. 12, no. 20, pp. 9679-9687, 2017.

[40] A. Taufik and S. S. S. Ahmad, "Land cover classification of Landsat 8 satellite data based on Fuzzy Logic approach," IOP Conference Series: Earth and Environmental Science, vol. 37, no. 1, 2016, doi: 10.1088/17551315/37/1/012062.

[41] M. W. Mwaniki, M. S. Moeller and G. Schellmann, "A comparison of Landsat 8 (OLI) and Landsat 7 (ETM+) in mapping geology and visualising lineaments: A case study of central region Kenya," International Archives of the Photogrammetry, Remote Sensing \& Spatial Information Sciences, vol. 40, no. 7W3, pp. 897-903, 2015, doi: 10.5194/isprsarchives-XL-7-W3-897-2015.

[42] M. Koesmono, Kusmana and N. Suwarna, "Geological Map Sheet Sindangbarang and Bandarwaru, Java," Bandung, 1996.

[43] M. Isa, D. P. Cesarian, I. A. Abir, E. Yusibani, M. S. Surbakti and M. Umar, "Remote sensing satellite imagery and in-situ data for identifying geothermal potential sites: Jaboi, indonesia," International Journal of Renewable Energy Development, vol. 9, no. 2, pp. 237-245, 2020, doi: 10.14710/ijred.9.2.237-245.

[44] D. Oikonomidis and K. Makrovasili, "Geological mapping using Landsat-7 satellite image, compared with GIS Data. Case study from Lake Volvi Basin, Central Macedonia, Greece," in 17th Meet. Assoc. Eur. Geol. Soc. The Geology in Digital Age: Proceedings of the 17th Meeting of the Association of European Geological Societies, no. July, pp. 37-41, 2011.

\section{BIOGRAPHIES OF AUTHORS}

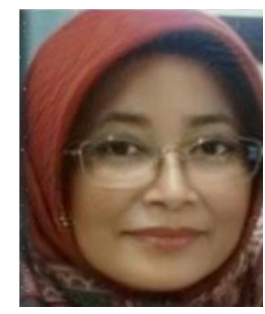

Yuliana Susilowati, is working as a Researcher in the Research Center for Geotechnology at Indonesian Institute of Sciences, Indonesia. She completed her Ph.D. in 2005 in the field of Computer Engineering from Electrical Engineering Department of Institute of Technology Bandung, Indonesia. Her research areas include Digital Image Processing, Remote Sensing, GIS and Environmental Modeling.

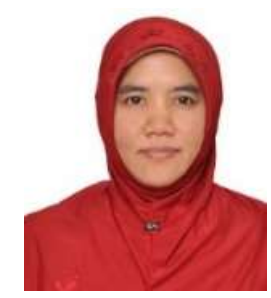

Pudji Irasari received electrical engineering degree in 1994 from Brawijaya University and master degree in renewable energy in 2003 from Oldenburg university. Her research areas include renewable energy and electric machine design. Currently she is a senior researcher under research group of Vibration Electric at Research Centre for Electrical Power and Mechatronics, Indonesian Institute of Sciences.

Bulletin of Electr Eng \& Inf, Vol. 10, No. 6, December 2021 : 3167-3177 


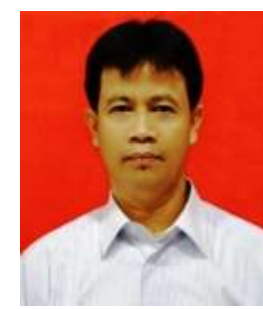

Yugo Kumoro, is working as a senior researcher in the Research Center for Geotechnology at Indonesian Institute of Sciences, Indonesia. He completed his Bachelor degree for Geological Engineering, Faculty of Mineral Technology, UPN "Veteran" Yogyakarta, Indonesia. His research areas include geology, geological engineering, and natural hazard.

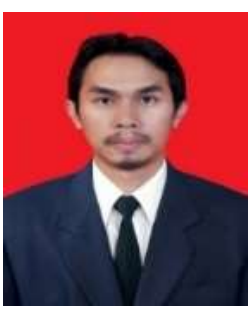

Wawan Hendriawan Nur, is working as a researcher in the Research Center for Geotechnology at Indonesian Institute of Sciences, Indonesia. He completed his Masters in Engineering from the School of Electrical and Informatics Engineering, Bandung Institute of Technology, Indonesia. His research areas include spatial information systems, geographical information systems, and spatial databases.

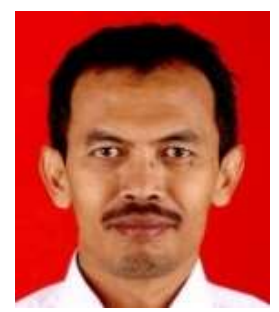

Yunarto, M.T., is working as a senior researcher in the Research Center for Geotechnology at Indonesian Institute of Sciences, Indonesia. He completed his Masters in Engineering from the Padjadjaran University, Bandung, Indonesia. His research areas include geology, natural hazard, vulnerability hazard, and socio-economical hazard. 